\title{
COMPARATIVE ACTION OF ACETYL-BETA-METHYL CHOLINE AND HISTAMINE ON THE RESPIRATORY TRACT IN NORMALS, PATIENTS WITH HAY FEVER, AND SUBJECTS WITH BRONCHIAL ASTHMA ${ }^{1}$
}

\author{
BY JOHN J. CURRY
}

(From the Evans Memorial, Massachusetts Memorial Hospitals and the Department of Medicine, Boston University School of Medicine)

(Received for publication November 16, 1946)

In a recent study (1), it was reported that the parenteral administration of histamine produced a sizable reduction of vital capacity in 8 of 9 actively asthmatic subjects, whereas it produced no significant change of vital capacity in 2 control groups of normal individuals and patients with hay fever. Furthermore, the effectiveness of histamine in producing a reduction in vital capacity varied in different asthmatic subjects and also in the same subject with the degree of asthma present at the time the tests were done. The present communication reports the action of acetyl-beta-methyl choline chloride (mecholyl chloride) on the vital capacity in asthmatic subjects, in patients with hay fever, and in a group of normal individuals and presents a comparison of the effect of mecholyl chloride with that of histamine. These assays were carried out in the hope of further elucidating the underlying mechanisms in asthmatic attacks.

In 1912, Barker and Sladen (2) noted the action of pilocarpine and atropine in bronchial asthma. Alexander and Paddock (3) induced "asthmatic-like" attacks in 10 of 20 patients with asthma by the subcutaneous injection of $3 \mathrm{mgm}$. pilocarpine. The latter workers observed that the systemic response to pilocarpine, as manifested by salivation, sweating, epiphora, flushing, and a sensation of warmth, was slightly greater in the asthmatic subjects than in the normal subjects. Starr, Elsom, Reisinger, and Richards (4) with the subcutaneous administration of $20 \mathrm{mgm}$. acetyl-beta-methyl choline inadvertently precipitated an "asthmatic-like" attack lasting 3 minutes in a young subject with a past history of asthma. Starr (5) also produced mild "asthmatic-like" attacks in asthmatic patients with acetyl-beta-methyl

1 This work was supported in part by a grant from the Upjohn Company, Kalamazoo, Michigan. choline chloride given orally. Villaret and his coworkers (6) gave 20 to $40 \mathrm{mgm}$. doses of acetylbeta-methyl choline subcutaneously to 1.5 asthmatic patients and produced in all of them "asthmaticlike" attacks which were regularly relieved by atropine. Moll (7) injected 5 to $20 \mathrm{mgm}$. doses of acetyl-beta-methyl choline subcutaneously in 28 asthmatic subjects and produced in 23 cases "asthmatic-like" attacks of varying intensity. The extra-pulmonary response to the drug in the asthmatic group did not differ from the response in the normal control subjects. Moll therefore made the suggestion that the peculiar tropism of choline derivatives for the lungs in asthmatic subjects was due to a local sensitivity rather than to a generalized state of increased sensitivity. Lung damage was considered an essential factor in determining the abnormal bronchial response. Dautrebande and Philippot (8) induced "asthmatic-like" attacks with aerosols of carbamino choline and studied the effectiveness of aerosols of phenyl amino propane in relieving these attacks. Ellis and Weiss (9) and Carmichael and Fraser (10) noted that when acetyl choline was given intravenously to normal subjects a sensation of substernal constriction was produced which was occasionally associated with coughing. Hurtado and Kaltreider (11) recorded a definite decrease in vital capacity associated with a sensation of substernal constriction and difficult breathing in 2 normal subjects following the intramuscular injection of acetyl-beta-methyl choline in doses of $30 \mathrm{mgm}$. and $15 \mathrm{mgm}$. respectively. Eppinger and Hess (12) in 1917 cited asthma as an example of pathologically increased vagotonia. One of the difficulties in accepting this theory of the etiology of asthma is the failure of atropine to give marked relief in the disease. Thus, while we have ob- 
served notable improvement both in symptoms and in the vital capacity in asthmatic subjects following adequate doses of atropine sulfate intravenously, there is no question that the relief is not so dramatic as that after epinephrine. While there has been no extensive study of blood cholinesterase levels in asthmatic patients, the few that have been determined have been within the normal range (13). More important than blood levels, however, would be a study of lung cholinesterase, since, if there is an excess liberation of acetyl choline in the lungs of the asthmatic subjects, one might expect an increased amount of cholinesterase to be present.

\section{MATERIALS AND METHODS}

Acetyl-beta-methyl choline, hereafter referred to as mecholyl chloride, ${ }^{2}$ was administered to 3 groups of subjects, and the reaction of the respiratory tract was measured chiefly by recording the vital capacity by a technic already described (1). The first group was composed of 10 normal subjects who had no recognizable symptoms or manifestations of allergy. The second group included 11 patients with seasonal hay fever who had neither a history nor signs or symptoms of asthma. These latter patients were also tested in the same way after the parenteral administration of histamine. The third group was composed of 27 asthmatic subjects, the majority of whom had mild continuing asthma. However, a few patients were included who had a history of typical asthmatic attacks in the past but who had had no recent signs or symptoms of asthma. As in the previous study, an attempt was made to secure young, cooperative subjects with vital capacities not subject to unaccountable variations. In all of these subjects the action of parenteral histamine on the vital capacity was also studied for purposes of comparison. Patient B: R., a 28-year-old, single female with mild chronic asthma, was again very cooperative and repeated studies were made with her assistance.

Mecholyl chloride was dissolved in sterile physiological saline to a concentration of $20 \mathrm{mgm}$. per $\mathrm{ml}$. for intramuscular injection and further diluted with sterile physiological saline to a concentration of $0.1 \mathrm{mgm}$. per $\mathrm{ml}$. for intravenous administration. Care was exercised in the preparation of the solutions because of the marked hygroscopic property of the salt. The solution was placed in a sterile rubber capped bottle which was stored in a refrigerator when not in use. A fresh solution was prepared at 2- to 3-week intervals. Unless otherwise stated the drug was injected in the deltoid muscle. In some of the asthmatic group the reaction to the intravenous administration and nebulization of the drug was also observed. The maximum dose employed was $6 \mathrm{mgm}$. because experience showed that with the patients in the sitting position larger doses sometimes produced untoward systemic effects, such as weakness and dizziness, which interfered

\footnotetext{
2 Merck \& Co., Inc.
}

with the performance of the vital capacity test. In the asthmatic group when wheezing or respiratory discomfort was present, doses of 0.25 to $0.50 \mathrm{mgm}$. were first administered to determine the reactiveness of the patient. The dosage was then increased up to $6 \mathrm{mgm}$. or until a significant reduction in the vital capacity was produced. The intravenous dose ranged from $0.005 \mathrm{mgm}$. to $0.6 \mathrm{mgm}$. For nebulization a 1:40,000 solution was used. The degree of flushing, salivation, sweating, and tachycardia which followed the administration of mecholyl chloride was also noted. Histamine acid phosphate, ${ }^{3}$ with $1 \mathrm{ml}$. equivalent to $0.2 \mathrm{mgm}$. histamine base, was given intravenously to the groups with hay fever and asthma in doses equivalent to 0.01 to $0.04 \mathrm{mgm}$. histamine base, except in a few instances when the drug was given intramuscularly. In the latter cases the dosage was increased.

\section{RESULTS AND COMMENTS}

\section{Intramuscular mecholyl chloride}

Normal SUbJects: In 3 of 10 normal individuals a dose of $6 \mathrm{mgm}$. mecholyl chloride caused a definite though slight reduction in the vital capacity measuring 4 per cent, 4 per cent, and 6 per cent respectively (Table I). The tests were repeated in

TABLE I

The effect of $6 \mathrm{mgm}$. mecholyl chloride given intramuscularly on the vital capacity in normal subjects

\begin{tabular}{|c|c|c|c|c|}
\hline \multirow{2}{*}{ Subject } & \multirow{2}{*}{ Age } & \multirow{2}{*}{ Sex } & \multicolumn{2}{|c|}{ Vital capacity } \\
\hline & & & Before drug & Change \\
\hline $\begin{array}{l}\text { S. L. } \\
\text { S. K. } \\
\text { W. H. } \\
\text { J. S. } \\
\text { P. K. } \\
\text { J. C. } \\
\text { R. S. }\end{array}$ & $\begin{array}{l}30 \\
30 \\
21 \\
25 \\
31 \\
32 \\
22\end{array}$ & $\begin{array}{l}M \\
M \\
F \\
M \\
M \\
M \\
M\end{array}$ & $\begin{array}{c}m l . \\
4,671 \\
4,494 \\
3,511 \\
4,723 \\
3,605 \\
4,347 \\
4,681\end{array}$ & $\begin{array}{l}\text { per cent } \\
-1 \\
-0.9 \\
+5 \\
-0.9 \\
+6 \\
-0.5 \\
-4 \\
-6\end{array}$ \\
\hline R. B. & 28 & M & $\begin{array}{l}4,010 \\
3,929\end{array}$ & $\begin{array}{l}-4 \\
-3\end{array}$ \\
\hline W.G. & 23 & M & $\begin{array}{l}4,891 \\
4,901\end{array}$ & $\begin{array}{l}-6 \\
-5\end{array}$ \\
\hline R. D. & 29 & $\mathbf{M}$ & 4,012 & +6 \\
\hline
\end{tabular}

these 3 subjects within a few days and similar effects were obtained. All of the normal subjects experienced a sensation of substernal constriction with difficulty in respiration. In spite of this, however, 3 subjects showed a slight increase in the vital capacity after the drug was administered. It is likely that normal individuals have a slight but variable sensitivity of the respiratory tract to

3 Eli Lilly Company. 
mecholyl and that, if the dosage is sufficiently increased, a reduction in vital capacity might be produced in all, as is suggested by the studies of Hurtado and Kaltreider (11). However, in a subject with mild chronic bronchitis who had no allergic tendencies, the administration of $6 \mathrm{mgm}$. mecholyl chloride produced a pronounced decrease in vital capacity. Therefore it was important to make certain that the normal group had no demonstrable respiratory tract disease. In the earlier study (1), among the 10 normal subjects given $0.03 \mathrm{mgm}$. histamine base intravenously, only 1 subject had a reduction in vital capacity of 3 per cent, 2 had a reduction of 2 per cent and 2 a reduction of 1 per cent. In the remainder the vital capacity increased following the administration of the drug.

TABLE II

The effect of mecholyl chloride and histamine base on the vital capacity of subjects with hay fever and no asthma

\begin{tabular}{|c|c|c|c|c|c|c|}
\hline \multirow[b]{2}{*}{ Subject } & \multirow[b]{2}{*}{ Age } & \multirow[b]{2}{*}{ Sex } & \multicolumn{2}{|c|}{ Drug administered } & \multicolumn{2}{|c|}{ Vital capacity } \\
\hline & & & $\begin{array}{l}\text { Mecholyl } \\
\text { chloride } \\
\text { I.M. }\end{array}$ & $\begin{array}{l}\text { Hista- } \\
\text { mine base } \\
\text { I.V. }\end{array}$ & $\begin{array}{l}\text { Before } \\
\text { drug }\end{array}$ & Change \\
\hline \multirow{2}{*}{ L. H. } & \multirow{2}{*}{48} & \multirow[b]{2}{*}{$\mathbf{F}$} & \multirow{2}{*}{$\begin{array}{c}\text { mgm. } \\
6\end{array}$} & $m g m$. & $m l$. & $\begin{array}{l}\text { per cent } \\
-2\end{array}$ \\
\hline & & & & & & $\begin{array}{l}-2 \\
+3\end{array}$ \\
\hline H. W. & 28 & $\mathbf{M}$ & 6 & & $\begin{array}{l}2,780 \\
4,514 \\
4,504\end{array}$ & $\begin{array}{c}+3 \\
-1 \\
+.04\end{array}$ \\
\hline \multirow{2}{*}{ J. U. } & \multirow{2}{*}{24} & \multirow{2}{*}{ M } & \multirow{2}{*}{6} & 0.03 & \multirow{3}{*}{$\begin{array}{l}4,786 \\
4,765 \\
4,264\end{array}$} & \multirow{2}{*}{$\begin{array}{l}-6 \\
-4\end{array}$} \\
\hline & & & & 0.03 & & \\
\hline H. A. & 24 & M & 6 & & & -3 \\
\hline E. B. & 23 & $\mathbf{M}$ & 6 & & 3,981 & -9 \\
\hline W. G. & 25 & M & 6 & & 4,608 & -8 \\
\hline F. R. & 23 & $\mathbf{M}$ & 6 & & 3,961 & -2 \\
\hline V. N. & 18 & $\mathbf{M}$ & 6 & 0.03 & $\begin{array}{r}4,055 \\
4,138\end{array}$ & $\begin{array}{l}-0.2 \\
-5\end{array}$ \\
\hline & & & & 0.03 & 4,190 & 0 \\
\hline L. N. & 33 & $\mathbf{M}$ & 6 & 00 & 4,514 & \\
\hline A. $\mathrm{H}$. & 23 & $\mathbf{F}$ & 6 & & 3,145 & -10 \\
\hline L. P. & 31 & $\mathbf{M}$ & 6 & 0.02 & $\begin{array}{l}3,260 \\
3,835\end{array}$ & $\begin{array}{l}-4 \\
-10\end{array}$ \\
\hline & & & & 0.02 & 3,919 & -4 \\
\hline
\end{tabular}

HAY FEVER : In the group of 11 patients with hay fever who had neither a history nor signs or symptoms of asthma, the intramuscular injection of $6 \mathrm{mgm}$. mecholyl chloride produced some decrease in vital capacity in all of the subjects (Table II). Seven had a decrease in vital capacity of 5 per cent or greater. In comparison the intravenous administration of 0.02 to $0.03 \mathrm{mgm}$. histamine base in this same group produced a decrease in vital capacity in 6 of the 11 subjects and in only 2 instances was the decrease greater than 5 per cent. It is difficult to evaluate changes in the vital capacity of less than 5 per cent since variations of this degree may occur in the resting vital capacities. Nevertheless mecholyl chloride in the dosage used was more effective than histamine in reducing the vital capacity in these subjects. The extrapulmonary response was not different in the hay fever group than in the normal group and in some instances the extrapulmonary reaction was waning as the respiratory tract reaction was increasing. The majority of these tests were performed during the pollen season although none of the subjects complained of symptoms at the time of the tests. This may be important, since Brown and his coworkers (14) have shown that patients with hay fever and no history of bronchial asthma may frequently show a diminished vital capacity during their pollen season. It would appear worthwhile to repeat the tests on the hay fever subjects when the pollen season is terminated. Whether the more reactive patients with hay fever are those who may in later years develop asthma is a matter for conjecture. An attempt to correlate the personal and familial allergic background of a larger group of these patients with the degree of respiratory sensitivity to mecholyl chloride and histamine is planned.

BRONCHIAL ASTHMA: In the group of 27 asthmatic subjects, all had a reduction in vital capacity after the intramuscular administration of from 1 to $6 \mathrm{mgm}$. mecholyl chloride, and in only 1 instance was this reduction less than 5 per cent. In this same group 22 of the 27 patients had a reduction in vital capacity after parenteral histamine and in only 1 of the reactive cases was the reduction less than 5 per cent. The pattern of response to mecholyl chloride was similar in all the reactive patients although the sensitivity varied greatly from patient to patient and in the same patient varied at different times, depending on the degree of asthma present when the test was performed.

As a rule, in patients with only occasional mild attacks of asthma or in those who had only a history of asthma, the respiratory tract was less reactive to mecholyl than in subjects with active bronchial asthma. Following the intramuscular administration of an effective dose of mecholyl 
chloride the vital capacity was reduced when measured 2 minutes later. At the 4-minute period in many instances and especially if the reaction was pronounced, a further decrease in vital capacity was found. At 6 minutes usually there was a return toward the resting levels in the vital capacity except in those cases when the reaction was severe. Depending then on the severity of the reaction, the vital capacity returned to the resting levels in from 10 to 30 minutes. For example, in patient B. R. after the resting vital capacities were determined, a dose of $0.5 \mathrm{mgm}$. mecholyl chloride was injected into the deltoid muscle. Two minutes later the vital capacity measured $1,881 \mathrm{ml}$., a fall of $1,233 \mathrm{ml}$. from the resting level of $3,114 \mathrm{ml}$. Four minutes after the injection the vital capacity was $1,787 \mathrm{ml}$., and at the 6-minute period measured $2,080 \mathrm{ml}$. Vital capacities were recorded at the 10-minute, 15-minute, and 20-minute periods and measured $2,727 \mathrm{ml} ., 2,968 \mathrm{ml}$., and $3,114 \mathrm{ml}$. respectively. The flushing, sensation of warmth, sweating, and salivation produced by the administration of the drug were minimal, but respirations were increased with audible inspiratory and expiratory wheezing. Subject J. H., on the other hand, had a resting vital capacity of $5,454 \mathrm{ml}$. and 2 minutes after the intramuscular injection of $4 \mathrm{mgm}$. mecholyl chloride the vital capacity measured $5,298 \mathrm{ml}$. Vital capacities were repeated at 4 minutes, 6 minutes, 10 minutes, and 20 minutes after the injection and measured 5,026 ml., 2,016 ml., 5,141 ml., and $5,507 \mathrm{ml}$. respectively.

When increasing amounts of mecholyl chloride were injected intramuscularly an increased response occurred, the vital capacity was further reduced, and the subjective symptoms were increased. In subject P. M., for example, after the resting vital capacities were determined, varied amounts of mecholyl chloride were administered by the intramuscular route. In order to eliminate the possibility of a cumulative effect of the drug, the doses were given at 20 -minute intervals in the following order, $2 \mathrm{mgm}$., $4 \mathrm{mgm}$., $6 \mathrm{mgm}$., $3 \mathrm{mgm}$., and $5 \mathrm{mgm}$. Vital capacities were measured at the usual intervals of 2 minutes, 4 minutes, 6 minutes, 10 minutes, and 20 minutes. The vital capacities recorded 4 minutes after each injection of the drug showed an increased reduction with increasing dosage of mecholyl chloride (Figure 1). When identical doses of mecholyl chloride were

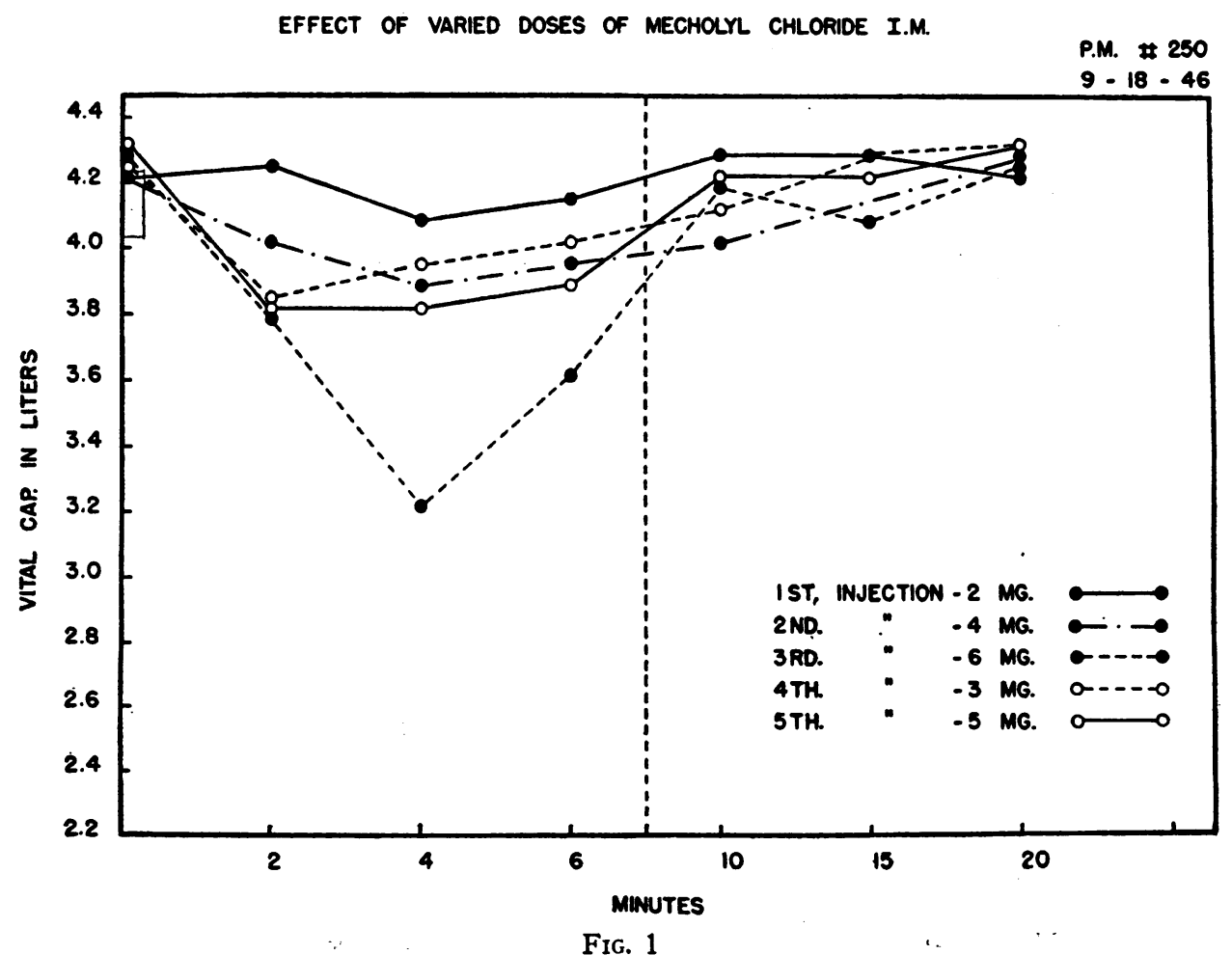


injected intramuscularly at 30-minute intervals, the decrease in vital capacity which resulted in some cases varied as much as $500 \mathrm{ml}$. In subject B. R., for example, 5 intramuscular injections of $0.4 \mathrm{mgm}$. mecholyl chloride at 30 -minute intervals resulted in a decreased vital capacity of $846 \mathrm{ml}$., $857 \mathrm{ml}$., $1,129 \mathrm{ml}$., $773 \mathrm{ml}$., and $658 \mathrm{ml}$. respectively. from a resting level of $3,385 \mathrm{ml}$. It is possible that these variations may be due to slight differences in the site of injection of the drug in the deltoid area since we have observed a difference in the reaction pattern when the drug is given subcutaneously. There is also suggestive evidence that with a less reactive subject and with larger doses of mecholyl chloride, from 4 to 6 mgm., used, a more uniform reduction in vital capacity is obtained with repeated identical doses of the drug. In a few instances when prostigmin methyl sulfate, in doses of 0.5 to $0.75 \mathrm{mgm}$., was administered, the effect of mecholyl chloride on the respiratory tract was markedly enhanced. In view of the severe reactions that we produced in actively asthmatic subjects with small doses of intramuscular mecholyl chloride, it is difficult to understand how the subjects given 20 to $40 \mathrm{mgm}$. mecholyl chloride subcutaneously by Villaret and his coworkers were able to tolerate the reaction. It is possible that the patients were suffering only mild bronchial asthma and that the difference in the site of administration of the drug and the supine position resulted in a lessened response to drug.

In the asthmatic group we were unable to detect any notable difference from the control groups in the extrapulmonary response to mecholyl chloride, as manifested by flushing, salivation, sensation of warmth, or tachycardia. These findings confirm those reported by Moll. However, the occurrence of an increased tracheobronchial reaction to mecholyl chloride in 3 normal patients and many of our hay fever control group and some asthmatic subjects without any obvious respiratory infection would seem to indicate that lung damage was not necessarily an essential factor in determining the abnormal bronchial response as suggested by the same author. While the precise cause of this abnormal tracheobronchial response in asthmatic subjects is not clear, studies are in progress which may throw some light on the mechanism. In one individual, S. G., a very mild asthmatic subject, $6 \mathrm{mgm}$. mecholyl chloride intramuscularly pro- voked an attack of uncontrolled auricular fibrillation, confirmed by electrocardiogram, which subsided spontaneously in 1 hour.

\section{Comparison of the effect on the respiratory tract of mecholyl chloride and histamine given parenterally}

Since there appeared to be a difference in the response of the tracheobronchial tree to histamine and mecholyl, it appeared worthwhile to ascertain that they acted independently. While it is generally agreed that the pharmacodynamic activity of the 2 drugs in the lungs differs, it seemed possible that in the deranged state of hyperresponsiveness of the respiratory tract one substance might act to some extent through liberation of the other. There also appears to be some relationship between histamine and mecholyl chloride in that antihistamine drugs have some degree of antiacetyl choline activity and antiacetyl choline drugs have some antihistamine activity. Therefore, in patient J. D., $0.02 \mathrm{mgm}$. histamine base was administered intravenously, and a reduction of $1,944 \mathrm{ml}$. in the vital capacity followed. When the vital capacity had returned to the resting levels, $1 \mathrm{mgm}$. mecholyl chloride was given intramuscularly and a reduction of $1,234 \mathrm{ml}$. resulted. After the vital capacity had again returned to the resting levels, a dose of $30 \mathrm{mgm}$. benadryl, a potent antihistamine agent (15), was given intravenously. When a dose of $0.02 \mathrm{mgm}$. histamine base, given intravenously, was now repeated a decrease in vital capacity of only $168 \mathrm{ml}$. occurred, whereas $1 \mathrm{mgm}$. mecholyl chloride intramuscularly caused a decrease of 1,348 $\mathrm{ml}$. Benadryl, therefore, afforded remarkable protection against the reduction in vital capacity due to histamine but gave no protection against the reduction due to mecholyl chloride. In patient B. R., after $30 \mathrm{mgm}$. benadryl had been given by vein and marked histamine protection resulted, a dose of 2 mgm. mecholyl chloride produced a pronounced reduction in vital capacity. In another experiment, in patient J. D., the reduction in vital capacity due to $0.01 \mathrm{mgm}$. histamine given intravenously was $481 \mathrm{ml}$. A dose of $0.75 \mathrm{mgm}$. prostigmin methyl sulfate was administered intramuscularly and a repeat injection of $0.01 \mathrm{mgm}$. histamine 20 minutes later produced a drop in vital capacity of $481 \mathrm{ml}$. Prostigmin did not augment the response to histamine. It appeared, therefore, that in the asth- 
TABLE III

Effect of mecholyl chloride and histamine base on the vital capacity of patients with moderately active asthma

\begin{tabular}{|c|c|c|c|c|c|c|}
\hline \multirow[b]{2}{*}{ Subject } & \multirow[b]{2}{*}{ Age } & \multirow[b]{2}{*}{ Sex } & \multicolumn{2}{|c|}{ Drug administered } & \multicolumn{2}{|c|}{ Vital capacity } \\
\hline & & & $\begin{array}{c}\text { Mecholyl } \\
\text { chloride } \\
\text { I.M. }\end{array}$ & $\begin{array}{l}\text { Hista- } \\
\text { mine base } \\
\text { I.V. }\end{array}$ & $\begin{array}{l}\text { Before } \\
\text { drug }\end{array}$ & Change \\
\hline & & & $m g m$. & mgm. & ml. & per cent \\
\hline B. $\mathbf{R}$. & 28 & $\mathbf{F}$ & 2 & & 3,365 & -76 \\
\hline A T & & & & 0.04 & 3,334 & -78 \\
\hline A. L. & 33 & $\mathbf{M}$ & 4 & 003 & $\begin{array}{l}4,504 \\
4,901\end{array}$ & $\begin{array}{l}-45 \\
-44\end{array}$ \\
\hline J. D. & 16 & F & 1 & & 3,103 & -46 \\
\hline$M$ & & & & 0.02 & 3,083 & -63 \\
\hline & 30 & $\boldsymbol{\Gamma}$ & 4 & 0.03 & $\begin{array}{l}5,390 \\
3,322\end{array}$ & $\begin{array}{l}-10 \\
-16\end{array}$ \\
\hline E. C. & 13 & F & 3 & & 1,787 & -51 \\
\hline F. G & 20 & $\mathbf{M}$ & 4 & 0.01 & $\begin{array}{l}1,891 \\
4,50\end{array}$ & $\begin{array}{l}-29 \\
-61\end{array}$ \\
\hline & & & & 0.03 & 4,107 & -9 \\
\hline V. B. & 49 & $\mathbf{M}$ & atomized & & 3,961 & -29 \\
\hline S. W. & 22 & F & 2 & 0.0 & $\begin{array}{l}3,793 \\
3,083\end{array}$ & $\begin{array}{l}-50 \\
-65\end{array}$ \\
\hline & & & & 0.01 & 3,752 & -54 \\
\hline R. B. & 19 & $\mathbf{M}$ & 2 & $00 ?$ & $\begin{array}{l}2,989 \\
2782\end{array}$ & $\begin{array}{l}-54 \\
-47\end{array}$ \\
\hline P. McD. & 20 & $\mathbf{M}$ & 6 & & 4,274 & -25 \\
\hline W. J. & 14 & $\mathbf{M}$ & 2 & 0.02 & 4,316 & -6 \\
\hline & 14 & & 2 & 0.01 & 2,236 & $\begin{array}{l}-31 \\
-29\end{array}$ \\
\hline R. B. & 25 & $\mathbf{F}$ & 2 & & 2,404 & -48 \\
\hline $\mathrm{I} S$ & 20 & $\mathbf{F}$ & 1 & 0.02 & $\begin{array}{l}2,435 \\
2,351\end{array}$ & -3 \\
\hline 1.3. & & $\boldsymbol{F}$ & 1 & 0.01 & $\begin{array}{l}2,351 \\
2,341\end{array}$ & $\begin{array}{l}-80 \\
-86\end{array}$ \\
\hline V. C. & 25 & $\mathbf{F}$ & 2 & & 2,153 & -18 \\
\hline S. M. & 37 & $\mathbf{M}$ & 4 & 0.02 & 2,905 & $\begin{array}{l}-14 \\
-25\end{array}$ \\
\hline & & & & 0.12 & 3,322 & $\begin{array}{l}-25 \\
-19\end{array}$ \\
\hline J. D. & 19 & $\mathbf{M}$ & 3 & $\begin{array}{l}\text { I.M. } \\
0.20\end{array}$ & $\begin{array}{l}4,389 \\
4,243\end{array}$ & $\begin{array}{l}-25 \\
-44\end{array}$ \\
\hline
\end{tabular}

matic individual the 2 drugs, histamine and mecholyl chloride, operated independently in producing a decrease in vital capacity.

The subjective response to both drugs in regard to the action on the respiratory tract in the asthmatic group was similar when the reaction was pronounced. The majority of subjects were unable to distinguish between them except that the mecholyl chloride response was less apt to disappear quickly. When the reaction was mild, however, the majority of subjects felt that the mecholyl chloride response was "more like a true asthmatic attack" than the histamine response.

In all patients with active bronchial asthma the respiratory tract was hyperreactive to both drugs; but, in the case of R. B., an active asthmatic, the degree of reduction in vital capacity from a dose of $0.02 \mathrm{mgm}$. histamine intravenously was only 3 per cent contrasted to a reduction in vital capacity of 48 per cent after the intramuscular injection of $2 \mathrm{mgm}$. mecholyl chloride. It appeared that the tracheobronchial tree was more reactive to mecholyl chloride than to histamine, since small doses of mecholyl chloride from 0.25 to $2.0 \mathrm{mgm}$. intramuscularly produced regularly a pronounced decrease in vital capacity (Table III).

In the group of asthmatics with only mild occasional attacks or with only a history of asthma, usually in childhood, sensitivity of the respiratory tract to mecholyl chloride was definitely more marked than sensitivity to histamine and sensitivity to both drugs was less than in the former group (Table IV). One patient, W. B., who had a history of asthma was not very reactive to either drug. A dose of $6 \mathrm{mgm}$. mecholyl chloride in this patient caused a reduction in vital capacity of only 3 per cent and the intravenous administration of 0.03 mgm. histamine was followed by a vital capacity greater than the resting value. In another patient, W. F., who had a history of typical asthma, an intramuscular dose of $6 \mathrm{mgm}$. mecholyl chloride caused a reduction of 31 per cent in the vital ca-

TABLE IV

Effect of mecholyl chloride and histamine base on the vital capacity of patients with mild, occasional bronchial asthma or a past history of asthma

\begin{tabular}{|c|c|c|c|c|c|c|}
\hline \multirow{2}{*}{ Subject } & \multirow{2}{*}{ Age } & \multirow{2}{*}{ Sex } & \multicolumn{2}{|c|}{ Drug administered } & \multicolumn{2}{|c|}{ Vital capacity } \\
\hline & & & $\begin{array}{l}\text { Mecholyl } \\
\text { chloride } \\
\text { I.M. }\end{array}$ & $\begin{array}{c}\text { Hista- } \\
\text { mine base } \\
\text { I.V. }\end{array}$ & $\begin{array}{c}\text { Before } \\
\text { drug }\end{array}$ & Change \\
\hline & & & mgm. & mgm. & $m l$. & per cent \\
\hline I. B. & 26 & $\mathbf{M}$ & & I.M. & $\begin{array}{l}3,375 \\
3,428\end{array}$ & $\begin{array}{r}-25 \\
-0\end{array}$ \\
\hline M. S. & 45 & F & 3 & & 3,250 & -37 \\
\hline D. D. & 43 & F & 6 & 0.0 & 2,581 & $\begin{array}{l}-19 \\
-10\end{array}$ \\
\hline W. B. & 27 & $\mathbf{M}$ & 6 & & 4,399 & -3 \\
\hline H. D. & 22 & $\mathbf{F}$ & 6 & 0.03 & $\begin{array}{l}4,430 \\
3,125\end{array}$ & $\begin{array}{l}+2 \\
-5\end{array}$ \\
\hline$R M$ & 22 & $\mathbf{F}$ & 6 & 0.03 & 3,240 & $\begin{array}{r}-5 \\
-18\end{array}$ \\
\hline & & & & 0.03 & 3,511 & -10 \\
\hline C. S. & 26 & $\mathbf{M}$ & 4 & 003 & $\begin{array}{l}4,180 \\
4358\end{array}$ & -12 \\
\hline S. G. & 21 & $\mathbf{F}$ & 6 & & 2,686 & -18 \\
\hline W. F. & 27 & $\mathbf{M}$ & 6 & 0.00 & 4,681 & -31 \\
\hline & 34 & $\mathbf{M}$ & 0 & 0.03 & $\begin{array}{l}4,807 \\
4,452\end{array}$ & $\begin{array}{l}-24 \\
-15\end{array}$ \\
\hline e. & & & & 0.02 & 4,201 & +1 \\
\hline G. C. & 37 & $\mathbf{M}$ & 6 & & $\begin{array}{l}4,608 \\
4,494\end{array}$ & $\begin{array}{l}-11 \\
-11\end{array}$ \\
\hline
\end{tabular}


pacity and $0.03 \mathrm{mgm}$. histamine base intravenously caused a reduction of 24 per cent. In 3 subjects with only mild occasional attacks of asthma, D. D., C. S., and S. G., mecholyl chloride caused significant decreases in vital capacity, whereas the intravenous administration of $0.03 \mathrm{mgm}$. histamine produced no decrease in vital capacity. In view of these findings it would appear that attention should be turned more towards discovering anticholinergic agents rather than antihistamine drugs for the treatment of bronchial asthma.

Since there is a possibility that respiratory hyperresponsiveness in the hay fever group may indicate those individuals who are potential asthmatics and since the differences in reaction of the asthmatic group to histamine and mecholyl chloride may serve to differentiate various types of asthma, it is planned to enlarge the group and attempt to correlate the reaction to the 2 drugs with the various clinical characteristics of the allergic state.

\section{Intravenous mecholyl chloride}

When mecholyl chloride was administered intravenously to asthmatic subjects, in doses of 0.005 to $0.6 \mathrm{mgm}$., the maximal reduction in vital capacity was noted in about 30 seconds and the vital capacity returned to the resting levels in 15 to 30 minutes. As might be expected with the larger doses a more pronounced reduction in vital capacity occurred and a longer time was required before the vital capacity returned to the resting levels. Thus, in subject B. R., the intravenous injection of $0.01 \mathrm{mgm}$. mecholyl chloride produced at the 30-second period a decrease of $760 \mathrm{ml}$. in the vital capacity, from the resting level of $3,170 \mathrm{ml}$. to $2,410 \mathrm{ml}$. Repeated vital capacities recorded at the 1.5, 3, 5, and 10-minute periods after the injection measured 2,510 ml., 2,770 ml., $2,950 \mathrm{ml}$., and $3,350 \mathrm{ml}$. respectively. In patient $\mathrm{W}$. G., on the other hand, a dose of $0.6 \mathrm{mgm}$. mecholyl chloride given by vein produced a reduction of 2,408 $\mathrm{ml}$. in the vital capacity from the resting level of $3,598 \mathrm{ml}$. to $1,087 \mathrm{ml}$. in 30 seconds after the injection. Repeated vital capacities were recorded at $1.5,3.5,5,10,20,30$, and 40-minute periods and measured 1,964 ml., $2,341 \mathrm{ml} ., 2,623 \mathrm{ml}$., 2,748 ml., 2,947 ml., 3,322 ml., and 3,469 ml. respectively. The intravenous injection of small amounts of mecholyl chloride produced a much greater reaction in the respiratory tract than much larger doses of the drug administered intramuscularly. Thus, in subject B. R., the intravenous injection of $0.1 \mathrm{mgm}$. mecholyl chloride caused a reduction of $1,800 \mathrm{ml}$. in the vital capacity as compared to a reduction of $310 \mathrm{ml}$. produced by the intramuscular injection of $0.25 \mathrm{mgm}$. of the drug. When an increased dose of mecholyl chloride is given intravenously, a greater reduction in vital capacity occurs. For example, in subject B. R., the administration of $0.01 \mathrm{mgm}$. mecholyl chloride intravenously caused a reduction of $762 \mathrm{ml}$. in the vital capacity, and, when subsequent doses of 0.03 mgm., $0.05 \mathrm{mgm} ., 0.08 \mathrm{mgm}$., and $0.10 \mathrm{mgm}$. of the drug were injected at 20-minute intervals, the following reductions in vital capacity were measured: $869 \mathrm{ml}$., $835 \mathrm{ml}$., 1,170 ml., and 1,798 ml. respectively (Figure 2 ). It may be seen that the $0.01 \mathrm{mgm}$., $0.03 \mathrm{mgm}$. and $0.05 \mathrm{mgm}$. doses produced a similar decrease in vital capacity but with larger doses notable increased reduction in vital capacity was observed. This same lack of sensitivity to small changes in dosage was brought out when increased doses of mecholyl chloride varying by only .005 and $.01 \mathrm{mgm}$. were injected intravenously and but slight variances in reduction of the vital capacity were recorded.

\section{Nebulized mecholyl chloride}

Nebulization of a 1:40,000 solution of mecholyl chloride produced a profound decrease in vital capacity which suggested that perhaps the respiratory tract is more reactive to the drug when it is administered in this manner. For example, in patient B. R., 4 inhalations from the nebulizer of mecholyl chloride produced a decrease in vital capacity of $2,111 \mathrm{ml}$. from a resting level of 2,769 $\mathrm{ml}$. to $658 \mathrm{ml}$. There was no evidence over a period of 5 minutes that the attack was subsiding and $0.85 \mathrm{mgm}$. atropine sulfate was given by vein with only partial relief and an increase in the vital capacity to $1,943 \mathrm{ml}$. Five minutes after the administration of $0.3 \mathrm{mgm} .1: 1,000$ epinephrine hydrochloride intramuscularly there was marked subjective relief and the vital capacity measured 3,344 $\mathrm{ml}$. It is interesting to note that in this case the relief afforded by atropine sulfate was not dramatic. 


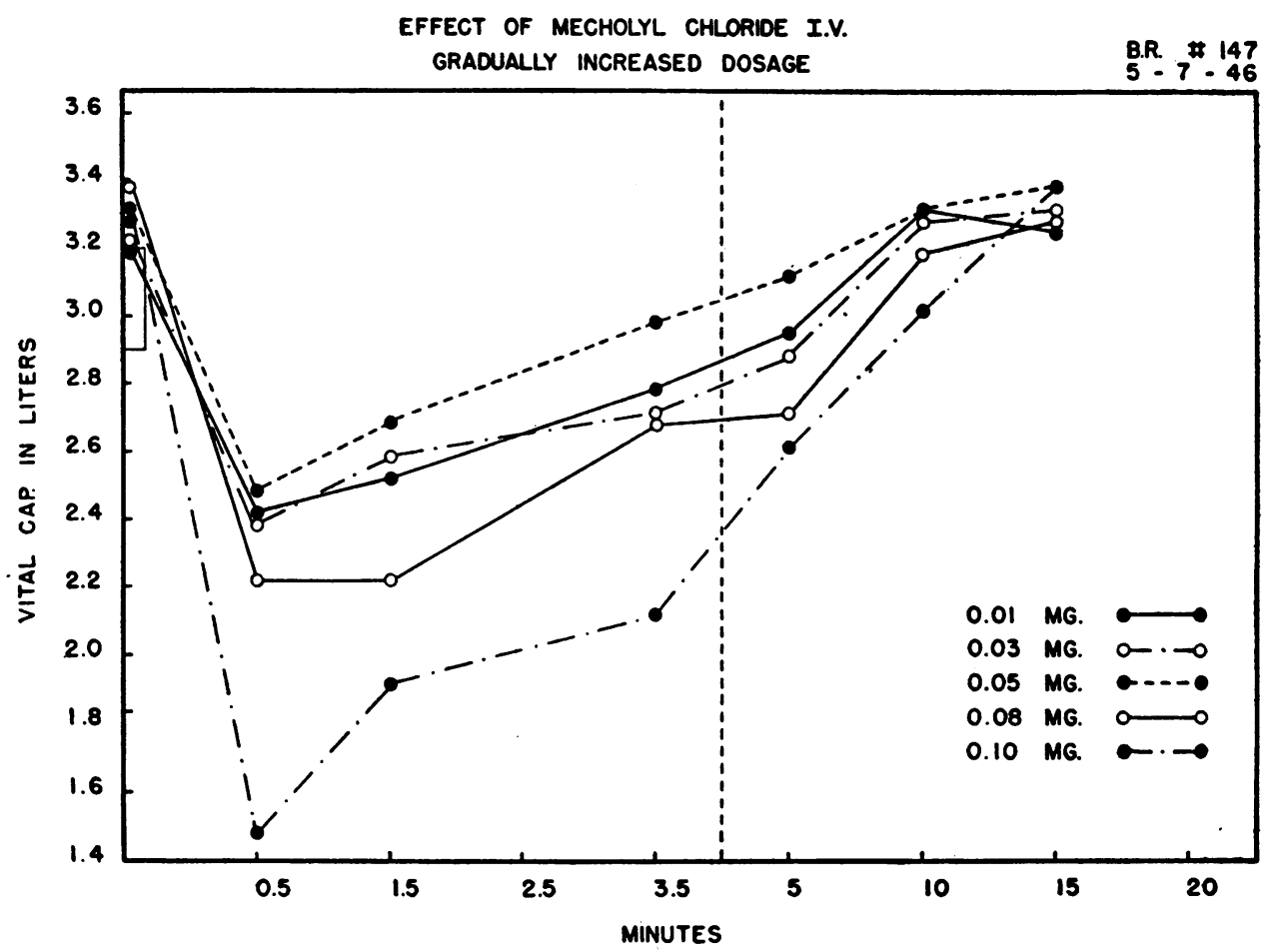

FIG. 2

\section{SUM MARY}

The reaction of the tracheobronchial tree, measured chiefly by changes in the vital capacity, to mecholyl chloride administered intramuscularly in doses of 0.25 to $6.0 \mathrm{mgm}$. was determined in 10 normal subjects, 11 patients with uncomplicated hay fever, and 27 patients with active bronchial asthma or a history of typical asthmatic attacks in the past. In the latter 2 groups, the reaction was compared with that due to parenteral histamine administered chiefly by the intravenous route in doses of 0.02 to $0.04 \mathrm{mgm}$. of the base. In the asthmatic group the reaction to intramuscular mecholyl chloride was studied in detail. The reaction to mecholyl chloride given intravenously and by nebulization was also studied in a few cases.

In the normal group, 3 subjects had a slight reduction in vital capacity after the intramuscular injection of $6 \mathrm{mgm}$. mecholyl chloride though all noted a feeling of tightness in the chest. In the group of 11 patients with hay fever, all had a slight reduction in vital capacity following the administration of $6 \mathrm{mgm}$. mecholyl chloride intramuscularly and in 7 cases the reduction was 5 per cent or greater. By contrast, in this latter group the intravenous administration of 0.02 to $0.03 \mathrm{mgm}$. histamine base caused a reduction in vital capacity in 6 of the 11 subjects but in only 2 cases was the decrease 5 per cent or greater.

In the group of 27 subjects with bronchial asthma or a history of typical asthmatic attacks in the past all had a reduction in vital capacity after the intramuscular injection of from 1 to $6 \mathrm{mgm}$. mecholyl and in only 1 instance was the decrease less than 5 per cent. On the other hand, following the administration of parenteral histamine 23 subjects had a reduction in vital capacity, and in 22 of these cases the reduction was $\mathbf{5}$ per cent or greater. It appeared that patients with hay fever and asthmatic subjects were more reactive to mecholyl chloride than to histamine and that both drugs acted by different mechanisms on the hyperresponsive respiratory tract of these individuals.

The pattern of reaction of the tracheobronchial tree to mecholyl chloride, as measured by the reduction in vital capacity, was similar in responsive individuals, though the degree of reaction varied from patient to patient and in the same patient with the degree of asthma present at the time the 
tests were performed. With increasing doses of the drug, an increased reduction in vital capacity resulted.

The intravenous injection of 0.005 to $0.6 \mathrm{mgm}$. mecholyl chloride produced a more pronounced decrease in vital capacity than the intramuscular injection, with its most notable effect in about 30 seconds after the injection. Nebulization of a $1: 40,000$ solution of mecholyl chloride produced a pronounced reduction in vital capacity which suggested that the tracheobronchial tree may be more reactive to the drug administered by this route.

The degree of extrapulmonary reaction to mecholyl chloride as indicated by flushing, sweating, salivation, tachycardia, and a feeling of warmth was no more notable in the asthmatic group than in the hay fever or normal groups. Paroxysmal auricular fibrillation occurred in 1 patient following a dose of $6 \mathrm{mgm}$. of mecholyl chloride intramuscularly.

\section{BIBLIOGRAPHY}

1. Curry, J. J., The action of histamine on the respiratory tract in normal and asthmatic subjects. J. Clin. Invest., 1946, 25, 785.

2. Barker, L. F., and Sladen, F. J., Tr. Assn. Am. Phys., 1912, 27, 471.

3. Alexander, H. L., and Paddock, R., Bronchial asthma : response to pilocarpin and epinephrin. Arch. Int. Med., 1921, 27, 184.

4. Starr, I., Jr., Elsom, K. A., Reisinger, J. A., and Richards, A. N., Acetyl-beta-methyl cholin. I. The action on normal persons: with a note on the action of the ethyl ether of beta-methyl cholin. Am. J. M. Sc., 1933, 186, 313.
5. Starr, I., Jr., Acetyl-beta-methyl cholin. III. Its action on paroxysmal tachycardia and peripheral vascular disease with a discussion of its action in other conditions. Am. J. M. Sc., 1933, 186, 330.

6. Villaret, M., Vallery-Radot, P., Justin-Besancon, L., and Claude, F., Preliminary research: On the attacks produced in certain asthmatic subjects by certain choline esters. Compt. Rend. de la Soc. Biol. 1934, 116, 1343.

7. Moll, H. H., The action of parasympathetic-mimetic drugs in asthma. Quart. J. Med., 1940, 9, 229.

8. Dautrebande, L., and Philippot, E., Experimental attacks of asthma by aerosols of carbamino choline in man and treatment by aerosol of phenylamino propane. Presse. Méd., 1941, 49, 942.

9. Ellis, L. B., and Weiss, S., Study of cardiovascular responses in man to intravenous and intra-arterial injection of acetyl choline. J. Pharmacol. \& Exper. Therap., 1932, 44, 235.

10. Carmichael, E. A., and Fraser, F. R.; The effects of acetyl choline in man. Heart, 1933, 16, 263.

11. Hurtado, A., and Kaltreider, N. L., Studies of total pulmonary capacity and its subdivisions. VII. Observations during the acute respiratory distress of bronchial asthma and following the administration of epinephrine. J. Clin. Invest., 1934, 13, 1053.

12. Eppinger, H., and Hess, L., Vagotonia, A Clinical Study in Vegetative Neurology, 2nd ed., New York, Nervous \& Mental Division Publishing Co., 1917.

13. Milhorat, A. T., The choline esterase activity of the blood serum in disease. J. Clin. Invest., 1938, 17, 649.

14. Brown, E. A., Nobili, C., Sannella, T., and Wadsworth, G. P., Dyspnea and diminished vital capacity as a symptom and a sign in hay fever. Dis. of Chest, 1946, 12, 205.

15. Curry, J. J., The effect of antihistamine substances and other drugs on histamine bronchoconstriction in asthmatic subjects. J. Clin. Invest., 1946, 25, 792. 